\title{
Typifications in Cordia (Cordiaceae), with an assessment of the status of Cordia blanchetii
}

\author{
María Natividad Sánchez de Stapf ${ }^{1,2}$ \& Tânia dos Santos Silva ${ }^{1}$
}

Summary. Typifications are proposed to facilitate ongoing studies in Cordiaceae and to maintain current usage. Lectotypes are designated for the following 13 names: Cordia ecalyculata, C. digyna, C. diospyrifolia, C. exaltata var. melanoneura, C. magnoliifolia, C. obscura var. tomentosa, C. obscura var. magnifolia, C. salicifolia, C. sellowiana, C. silvestris, C. ulei, C. ucayaliensis, and Patagonula glaziovii. Two new synonyms are proposed: C. crenatifolia Rizzini to C. glazioviana (Taub.) Gottschling \& J. S. Mill. and C. araripensis Rizzini to C. bicolor A. DC. Additionally, nomenclatural notes on C. blanchetii are provided.

Key Words. Brazil, lectotype, neotype, nomenclatural synonyms, Patagonula, synonym.

\begin{abstract}
Introduction
Cordia L. is the largest genus of Cordiaceae, with about 250 species, and its distribution is pantropical (Miller 2001; Gottschling \& Miller 2006). In Brazil, approximately 45 species occur, most concentrated in evergreen lowland and seasonally dry tropical forest (Stapf et al. 2010). Cordia is characterised by its style with four stigmatic lobes, undivided endocarp, plicate cotyledons, and pollen grains 3-colporate or 3-colpate with the tectum striate to striate-reticulate or spinulose. Recent phylogenetic studies (Gottschling et al. 2005) supported the monophyly of the genus Cordia. Despite the availability of relatively recent taxonomic treatments for some Brazilian species, many names are still in need of typification. This paper presents nomenclatural updates and taxonomic notes for the appropriate taxa, according to ICBN rules (McNeill et al. 2006). This work was carried out as part of the PhD studies of Brazilian Cordia species by the first author. Protologues were examined and original collections were studied in the following herbaria: B, BM, BR, C, G, G-DC, HAL, HUEFS, GH, K, M, NY, P, P-LA, PEUFR, OXF, R, RB, US and W (acronyms according to Thiers 2008+).
\end{abstract}

Cordia bicolor A. DC. (Candolle 1845: 485). Lithocardium bicolor (A. DC.) Kuntze (1891: 976). Gerascanthus bicolor (A. DC.) Borhidi et al. (1988: 399). Type: Suriname, without locality, Hostmann 406 (lectotype G-DC!, selected by Miller (1988); isolectotypes BM!, G!, K!, M!, NY!, OXF!, P!).
Cordia trichostyla Pittier (1917: 252). Type: Guatemala, Alta Verapaz, 550 m, 30 April 1905, Pittier 189 (holotype US!).

Cordia carnosa Rusby (1920: 104). Type: Venezuela, lower Orinoco, 1896, Rusby E Squires 418 (holotype $\mathrm{NY}$ !; isotypes $\mathrm{GH}$ !, $\mathrm{K}$ !, $\mathrm{M}$ !).

Cordia belizensis Lundell (1943: 488). Type: Belize, Toledo, 5 July 1942, Gentle 4045 (holotype MICH n.v.; isotype NY!).

Cordia araripensis Rizzini (1976: 180), synon. nov. Type: Brazil, Ceará, Crato, Floresta Nacional Chapada do Araripe, 29 Oct. 1965, Sobrinho 138 (holotype RB!; isotype PEUFR!).

DISTRIBUtION. Southern Mexico, Central America to northern South America in Colombia, Venezuela, Peru, Guyana, French Guiana, Suriname, Brazil, and Bolivia.

NOTES. Rizzini (1976) described Sobrinho 138, collected in the 'Serra do Araripe', Ceará, as a new species, Cordia araripensis Rizzini. He characterised it as differing by the fulvo-tomentose indumentum and rough, oblong leaves. However, an examination of the type of $C$. araripensis, at $\mathrm{RB}$ and the isotype at PEUFR, proves that this taxon is conspecific with $C$. bicolor.

Cordia bicolor is distinguished by the paler surface of abaxial leaves, the strigillose to scabrous indumentum with the trichomes borne on the veins and veinlets which converge over and cover the veinlet-areoles, and also its fruits that are minutely

\footnotetext{
Accepted for publication 22 April 2013. Published online 12 May 2013

1 Departamento de Ciências Biológicas, Universidade Estadual de Feira de Santana, Av. Transnordestina s.n., CEP 44036-900, Feira de Santana, Bahia, Brazil. e-mail: stapfm@si.edu

2 Smithsonian Tropical Research Institute, Apartado, 0843-03092, Balboa, Panama.
} 
strigose with the stylar scars clearly defined. $C$. bicolor is similar to C. scabrifolia A. DC.; both have fruits strigillose, but $C$. scabrifolia differs by its leaves drying brown and the trichomes borne on the veins and veinlets are directed towards the centre of the areoles, but never covering them, and the corolla tube shorter (2.8 - $3.2 \mathrm{~mm}$ long).

Cordia blanchetii A. DC. (Candolle 1845: 477). Lithocardium blanchetii (A. DC.) Kuntze (1891: 976). Type: Brazil, Bahia, Jacobina, 1836, Blanchet 2618 (holotype G-DC!; isotype P!).

DISTRIBUtION. Bahia and Minas Gerais states, Brazil. HABITAT. Cordia blachetii is known from semi-deciduous tropical forest; $150-650 \mathrm{~m}$ alt.

NOTES. Johnston (1930) did not recognise Cordia blanchetii A. DC. as a distinct taxon and treated it as synonym of $C$. superba Cham. However, an examination of the type specimen in G-DC and the duplicate at $\mathrm{P}$, has confirmed that it should be treated as a distinct taxon.

Cordia blanchetii is characterised by its 6 to 12 flowered inflorescences, with peduncles well developed (4.5 - $6.5 \mathrm{~cm}$ long); calyx regularly 5-lobed with the lobes acuminate (the acumen $3-3.2 \mathrm{~mm}$ long); and the corolla lobes wrinkled and sparsely pubescent on the outer surface. C. superba, in turn, is characterised by the calyx irregularly 3 to 5-lobed and the corolla lobes smooth and glabrous.

Cordia blanchetii most resembles C. aberrans I. M. Johnst., but they can be easily distinguished from each other since the latter species has the leaves ovate and flowers apparently springing directly from the leaf axils, and the leaves of $C$. blanchetii are oblanceolate to narrowly elliptic and the flowers are borne on cymes with well-developed terminal peduncles.

Cordia ecalyculata Vell. (Velloso 1827: Tab. 149). Gerascanthus ecalyculatus (Vell.) Borhidi et al. (1988: 399). Type: Fl. Flumin. p. 96, Tab. 149 (1825, 1827) (lectotype, selected here).

Cordia salicifolia Cham. (Chamisso 1829: 481). Lithocardium salicifolium (Cham.) Kuntze (1891: 977). Gerascanthus salicifolius (Cham.) Borhidi et al. (1988: 401). Type: Brazil, without locality, Sellow s.n. (lectotype K!, selected here; isolectotype $\mathrm{P}$ !).

Cordia digyna Vell. (Velloso 1827: Tab. 153). Type: Fl. Flumin. p. 97, Tab. 153 (1825, 1827) (lectotype, selected here).

Cordia leptocaula Fresen. (Fresenius 1857: 14). Lithocardium leptocaulon (Fresen.) Kuntze (1891: 977). Type: Brazil, Rio de Janeiro, Serra do Macacu, Pohl s.n., Herb. Mus. Vind. 1924 (holotype W n.v.; isotypes K!).
Cordia coffeoides Warm. (Warming 1867: 4). Type: Brazil, Minas Gerais, in silvis ad Lagoa Santa, 1865, Warming s.n. (holotype M!; isotypes C!, US!).

Patagonula glaziovii Mez (1890: 17). Cordia glaziovii (Mez) Taub. (Taubert 1893: Beibl. 38: 14). Gerascanthus glaziovii (Mez) Borhidi et al. (1988: 404). Type: Brazil, Glaziou 13476 (lectotype K!, selected here; isolectotypes G!, P!).

DISTRIBUTION. Brazil, Argentina and Paraguay.

NOTES. Cordia ecalyculata, like C. magnoliifolia Cham., has both surfaces of the leaves glabrous, flowers distylous and glabrous fruit. But $C$. ecalyculata has globose flowers buds and smaller and narrower leaves (5.5- $13.0 \mathrm{~cm}$ long, $2.5-3.5 \mathrm{~cm}$ wide) as compared to C. magnoliifolia which has obovoid buds and larger leaves (18.5 - $27.5 \mathrm{~cm}$ long and $4.5-8.5 \mathrm{~cm}$ wide).

Cordia exaltata Lam. (Lamarck 1791: 422). Lithocardium exaltatum (Lam.) Kuntze (1891: 977). Gerascanthus exaltatus (Lam.) Borhidi et al. (1988: 399). Type: French Guiana, without locality, Richard s.n. (holotype P-LA!; isotype P!).

Cordia scabrida Mart. ex Fresen. (Fresenius 1857: 11). Lithocardium scabridum (Mart. ex Fresen.) Kuntze (1891: 439). Gerascanthus scabridus (Mart. ex Fresen.) Borhidi et al. (1988: 402). Type: Brazi, Pará, in silvus, Martius 2597 (holotype M!; isotype BR!).

Cordia exaltata var. melanoneura I. M. Johnst. (Johnston 1935: 30). Cordia melanoneura Klotzsch in M. R. Schomb. (Schomburgk 1848: 960), nom. nud. Type: British Guiana, without locality, Schomburgk 1398 (lectotype K!, selected here).

DISTRIBUtION. Venezuela, Guyana, Suriname, French Guiana, and Brazil.

NOTES. Cordia exaltata is distinguished by its dimorphic leaves, tubular corolla (9.8 - $12 \mathrm{~mm}$ long) and ball-shaped glands on the prolonged connective above the anthers. It is similar to $C$. panicularis Rudge, but the latter differs in its homomorphic leaves, smaller corolla $(8.4-8.8 \mathrm{~mm}$ long $)$ and funnel-shaped calyx.

Cordia glazioviana (Taub.) Gottschling E J. S. Mill. (Gottschling \& Miller 2006: 364). Auxemma glazioviana Taubert (1892: 11). Type: Brazil, without precise locality, Glaziou 11287 (holotype: B n.v.; isotype: P!, $\mathrm{R} !)$.

Cordia crenatifolia Rizzini (1974: 12), synon. nov. Type: Brazil, Bahia, Campo Formoso, Fazenda Tiririca, Lima 13112 (holotype RB!).

DISTRIBUTION. Brazil and Paraguay. HABITAT. Seasonally dry tropical forests. 
NOTES. Rizzini (1974) described Cordia crenatifolia based on Lima 13112. We studied this specimen and found its general morphology to be similar to that of C. glazioviana.

Cordia magnoliifolia Cham. (Chamisso 1829: 476). Lithocardium magnoliifolium (Cham.) Kuntze (1891: 977). Gerascanthus magnoliifolius (Cham.) Borhidi et al. (1988: 400). Type: Brazil, without locality, Sellow s.n. (lectotype; K!, selected here; isolectotypes HAL!, P!, US!).

Cordia obliqua Vell. (Velloso 1827: Tab. 150), nom. illegit., (non C. obliqua Willd.). Lithocardium obliquum Kuntze (1891: 977). Type: Fl. Flumin. p. 97., Tab. 150 (1825, 1827).

Cordia diospyrifolia Cham. (Chamisso 1829: 477). Lithocardium diospyrifolium (Cham.) Kuntze (1891: 977). Type: Brazil, Sellow s.n. (lectotype HAL!, selected here; isolectotype $\mathrm{B} \dagger$ photo $\mathrm{G}$ !).

DISTRIBUTION. Cordia magnoliifolia is known only from Atlantic coast forest in Brazil.

NOTES. Cordia magnoliifolia was described by Chamisso (1829) based on a collection of Sellow collected in 'Brasilia aequinoctiali' and deposited in B. This specimen was destroyed during the Second World War, but there are duplicates in the K, P and US. We named the duplicate deposited in $\mathrm{K}$ as lectotype of this taxon because it is in good condition and fits the protologue description. There is a photo in $\mathrm{G}$ of the type material from $B$, which was also useful for the delimitation of the taxon.

Cordia magnoliifolia is distinctive in its large, oblanceolate and glabrous leaves. It is close to $C$. ecalyculata which has leaves glabrous on both surfaces, flowers distylous, and glabrous fruits. However, C. ecalyculata has globose flower buds and smaller leaves $(5.5-13.0 \mathrm{~cm}$ long $)$ and $C$. magnoliifolia has obovoid flowers buds and larger leaves (18.5 - $27.5 \mathrm{~cm}$ long).

Cordia sellowiana Cham. (Chamisso 1829: 478). Lithocardium sellowianum (Cham.) Kuntze (1891: 977). Gerascanthus sellowianus (Cham.) Borhidi et al. (1988: 402). Type: Brazil, without locality, Sellow s.n. (lectotype: G!, selected here).

Cordia obscura Cham. var. tomentosa Cham. (Chamisso 1833: 128). Type: Brazil, without locality, Sellow s.n. (lectotype G!, selected here; isolectotype HAL photo!, P!).

Cordia brachypoda A. DC. (Candolle 1845: 487). Lithocardium brachypodum (A. DC.) Kuntze (1891: 976). Gerascanthus brachypodus (A. DC.) Borhidi et al. (1988: 399). Type: Brazil, Bahia, 1832, Blanchet 648 (holotype G-DC!).
Cordia obscura Cham. var. magnifolia Fresen. (Fresenius 1857: 15). Type: Brazil, Minas Gerais, near Serra da Caraça, Martius 1119 (lectotype M!, selected here; isolectotypes $\mathrm{M}$ !)

DISTRIBUTION. Cordia sellowiana is known only from Brazil, in the Alagoas, Bahia, Ceará, Distrito Federal, Mato Grosso, Paraíba, Pernambuco, Distrito Federal, Goias, Rio de Janeiro, and São Paulo states.

HABITAT. It occurs in lowland and submontane forest, sometimes in montane forest, semi-deciduous forest and gallery forest; $100-1100 \mathrm{~m}$ alt.

NOTES. Cordia sellowiana is variable in pubescence. For this reason, there have been several names for this taxon. The taxa C. sellowiana, C. obscura var. tomentosa and $C$. brachypoda are copiously pubescent with spreading hairs and clear tomentosum on the abaxial leaf surface. Meanwhile, C. obscura has sparse pubescence, appearing glabrous. The latter species was described by Chamisso (1829) based on Sellow's material deposited in $\mathrm{B}$, which was destroyed during the Second World War.

Fresenius (1857) did not indicate a holotype when he described Cordia obscura var. magnifolia. He mentioned two syntypes, both with the same number (Martius 1119) but collected in Minas Gerais with different localities: (1) in montibus inter Ouro Preto et oppidum Praesidio de S. João Bapt. and (2) near Serra da Caraça, both deposited in M.

Cordia sellowiana is easy to recognise by its homomorphic leaves with the adaxial surface strigose and abaxial surface tomentose, calyx at anthesis opening regularly into 5 lobes and glabrous fruit. This species can be confused with $C$. toqueve Aubl., which has similar foliage, but $C$. toqueve has dimorphic leaves and pubescent fruit.

Cordia silvestris Fresen. (Fresenius 1857: 12). Lithocardium silvestre (Fresen.) Kuntze (1891: 976). Type: Brazil, Rio de Janeiro, silvis a campinho usque in Serram, 1500 ped., Dec., Martius 299 (lectotype M!, selected here).

DISTRIBUTION. Known only from Brazil, in Minas Gerais, Paraná, Rio de Janeiro, Rio Grande do Sul, and Santa Catarina.

NOTES. Cordia silvestris is easily recognised by its obovate or oblanceolate leaves $(5.8$ - $13.4 \mathrm{~cm}$ long) with a glabrous adaxial surface and a calyx which is pyriform in bud opening regularly into 5 lobes. It closely resembles $C$. ecalyculata which has the elliptic to elliptic-lanceolate leaves and a globose calyx opening irregularly into 3 or 4 lobes.

Martius 299 was designated as lectotype. The other syntype Schott s.n., Herb. Vindob. 4949 should be in W, but we had difficulties in obtaining loans or photos of it. 
Cordia ucayaliensis (I. M. Johnst.) I. M. Johnst. (Johnston 1935: 181). Cordia ulei I. M. Johnst. var. ucayaliensis I. M. Johnst. (Johnston 1930: 57). Gerascanthus ucayaliensis (I. M. Johnst.) Borhidi et al. (1988: 403). Type: Peru, Loreto, Yarina Cochas, Tessmann 5457 (lectotype NY!, selected here; isolectotypes $\mathrm{GH}$ !).

DISTRIBUTION. Brazil and Peru.

NOTES. Cordia ucayaliensis is characterised by leaves elliptic and strigose on both surfaces, and glabrous fruits. It resembles $C$. ulei I. M. Johnst., since both have glands on the anthers and glabrous fruits, but the corolla tube is shorter in C. ucayaliensis (4.5-5.2 mm long).

Cordia ulei I. M. Johnst. (Johnston 1930: 56). Gerascanthus ulei (I. M. Johnst.) Borhidi et al. (1988: 403). Type: Brazil. Acre, Rio Acre, Seringal São Francisco, March 1911, Ule 9716 (lectotype K! selected here; isolectotypes G!).

DISTRIBUTION. Known only from Brazil, occurring in Acre, Amazonas, Pará, and Rondônia states.

NOTES. Cordia ulei is characterised by obovate-elliptic or oblong-lanceolate leaves and glabrous ovary and fruits. The leaves are broadest above the middle and larger, like those of $C$. sellowiana, but in C. ulei the adaxial surface of the leaves are glabrous except along the midrib and the principal nerves, whereas in $C$. sellowiana the adaxial surface of the foliage is always pubescent. C. ulei resembles C. exaltata, however the latter has a larger corolla (9.8 - 12 $\mathrm{mm}$ long) and bears glands on the anthers.

\section{Acknowledgements}

Financial support for this research was provided by Organization American States (OAS) and Secretaria Nacional de Ciencia y Tecnologia (SENACYT) of Panama as PhD fellowship for the first author, who also received support of Kew Latin America Research Fellowship Programme (KLARF), to visit of European herbaria. T. R. S. Silva was supported by CNPq. We are grateful to the herbarium curators who provided loans or access to their collections.

Open Access This article is distributed under the terms of the Creative Commons Attribution License which permits any use, distribution, and reproduction in any medium, provided the original author(s) and the source are credited.

\section{References}

Borhidi, A., Gondár, E. \& Orosz-Kovács, Z. S. (1988). The re-consideration of genus Cordia L. Acta Bot. Hung. 34 (3 - 4): 375 - 423.
Candolle, A. P. de. (1845). Borragineae. In: A. de Candolle (ed.), Prodromus Systematis Naturalis Regni Vegetabilis 9, pp. 467 - 501. Treuttel \& Würtz, Paris. Chamisso, A. (1829). IV. Cordieae. Linnaea 4: 471 - 492. (1833). Spicilegium plantarum e familiis jam prius recensitis praesertim Brasiliensium serius a Sellowio missarum. Linnaea 8: 113 - 130.

Fresenius, G. (1857). Cordiaceae: In: K. F. P. von Martius, A. G. Eichler, S. L. Endlicher \& I. Urban (eds), Flora Brasiliensis 8 (1), pp. 1 - 28. Leipzig, Munich.

Gottschling, M. \& Miller, J. S. (2006). Clarification of the taxonomic position of Auxemma, Patagonula, and Saccellium (Cordiaceae, Boraginales). Syst. Bot. 31: 361 - 367.

, Miller, J. S., Weigend, M. \& Hilger H. H. (2005). Congruence of a phylogeny of Cordiaceae (Boraginales) inferred from ITS1 sequence data with morphology, ecology, and biogeography. Ann. Missouri Bot. Gard. 92: 425 - 437.

Johnston, I. M. (1930). Studies in the Boraginaceae, VIII. Observations on the species of Cordia and Tournefortia known from Brazil, Paraguay, Uruguay, and Argentina. Contr. Gray Herb. 92: 3 - 89.

(1935). Studies in Boraginaceae, X. The Boraginaceae of northeastern South America. J. Arnold. Arbor. 16 (1): 1 - 64.

Kuntze, O. (1891). Revisio Genera Plantarum, Vol. 2., Leipzig.

Lamarck, J. B. (1791). Tableau Encyclopédique et Méthodique. Ed. 1. Vol. 1: 418 - 423. Paris.

Lundell, C. L. (1943). New vascular plants from Texas, Mexico, and Central America. Amer. Midl. Naturalist 29 (2): $488-489$.

McNeill, J., Barrie, F. R., Burdet, H. M., Demoulin, V., Hawksworth, D. L., Marhold, K., Nicolson, D. H., Prado, J., Silva, P. C., Skog, J. E., Wiersema, J. H. \& Turland, N. J. (eds) (2006). International Code of Botanical Nomenclature (Vienna Code). Regnum Veg. 146.

Mez, C. C. (1890). Borragineae. In: P. H. W. Taubert, Plantae Glaziovianae novae vel minus cognitae. Bot. Jahrb. Syst. 12 (1 - 2, Beibl. 27): 17.

Miller, J. S. (1988). A revised treatment of Boraginaceae for Panama. Ann. Missouri Bot. Gard. 75 (2): 456 - 521. (2001). Two new species of Cordia (Boraginaceae) from Madagascar. Adansonia (Ser. 3) 23: 289 - 295.

Pittier, H. (1917). New or noteworthy plants from Colombia and Central America. Contr. U.S. Natl. Herb. 18(6): 225 - 259.

Rizzini, C. T. (1974). Plantas novas da Bahia. Leandra 4 5: 12.

(1976). Contribução ao conhecimento das Floras Nordestinas. Rodriguesia 40: 180.

Rusby, H. H. (1920). Descriptions of three hundred new species of South American Plants, p. 104. Published by the author at New York. 
Schomburgk, M. R. (1848). Boraginaceae. Reis. Br.-Guiana 3: 960.

Stapf, M., Taroda, N. \& T. R. Silva. (2010). A new species of Cordia (Cordiaceae, Boraginales) from Brazil. Novon 20: 212 - 214.

Taubert, P. H. W. (1892). Plantae Glaziovianae novae vel minus cognitae. Bot. Jahrb. Syst. 15 (2, Beibl. 34): 11 .

(1893). Plantae Glaziovianae novae vel minus cognitae. Bot. Jahrb. Syst. 15 (5, Beibl. 38): 14.
Thiers, B. (2008+) [continuously updated]. Index herbariorum: a global directory of public herbaria and associated staff. New York Botanical Garden: published at http:/ /sweetgum.nybg.org/ih/

Velloso, J. M. (1825). Florae Fluminensis: Cordia, pp. 96 98. Typographia Nationali, Rio de Janeiro.

(1827). Florae Fluminensis Icones: Cordia. Paris.

Warming, E. (1867). Symbolae ad floram Brasiliae centralis cognoscendam. Vidensk. Meddel. Naturhist. Foren. Kjøbenhavn $1-3: 4-6$. 